\title{
Inocybe mytiliodora: A New Record for Turkey
}

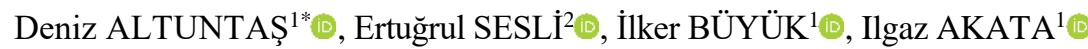 \\ ${ }^{1}$ Ankara University, Faculty of Science, Department of Biology, Ankara, TURKEY \\ ${ }^{2}$ Karadeniz Technical University, Faculty of Science, Department of Biology, Trabzon, TURKEY \\ *Corresponding author: fungus@ hotmail.com.tr
}

Received Date: 07.03.2019

Accepted Date: 18.07.2019

\begin{abstract}
Aim of the study: The aim of the present study is to identify, characterize and record a new agaric for the first time from Turkey.

Study area: It covers a total area of approximately 20 ha and is located in Ankara within the boundaries of Çankaya district.

Material and method: Basidiomata were collected from Ankara University Tandoğan Campus on September 1, 2018. Macro- and micromorphological properties of basidiomata and nuclear ribosomal large subunit (nrLSU) sequences were used for identification. The voucher specimens were kept at Ankara University Herbarium (ANK).

Main results: Based on the high sequence similarity between the new record (hereafter referred to as 'Ank Akata \& Altuntaş 167') and Inocybe mytiliodora, the specimen was identified as I. mytiliodora. This result is also supported by the morphological data derived from the evaluation of macroscopic and ecological features of the fruiting bodies between 'Ank Akata \& Altuntaş 167' and closely related fungi.

Research highlights: As a result, the basidiomata collected from Ankara University Tandoğan Campus represent 'Inocybe mytiliodora' and this is the first known record for Turkey.
\end{abstract}

Keywords: Inocybe mytiliodora, nrLSU, Ankara, Molecular Phylogeny, New Record

\section{Inocybe mytiliodora: Türkiye İçin Yeni Bir Kayıt}

Öz

Çalışmanın amacı: Bu çalışmanın amacı yeni bir şapkalı mantarı Türkiye için ilk kez, tanımlamak, karakterize etmek ve tanıtmaktır.

Çalışma alanı: Çalışma alanı Ankara Çankaya ilçesi sınırları dahilinde bulunmakta ve toplam 195.000 $\mathrm{m}^{2}$ lik bir alanı kaplamaktadır.

Materyal ve yöntem: Bazidiyomalar 1 Eylül 2018'de Ankara Üniversitesi Tandoğan Kampüsü'nden toplanmıştır. Teşhis için bazidiyomaların makro ve mikromorfolojik özelliklerinden ve nükleer büyük ribozomal alt ünite (nrLSU) sekanslarından faydalanılmıştır. Kurutulmuş örnekler Ankara Üniversitesi Herbaryumunda (ANK) saklanmaktadır.

Temel sonuçlar: Yeni kayıt (bundan böyle "Ank Akata ve Altuntaş 167” olarak anılacaktır) ve Inocybe mytiliodora arasındaki yüksek sekans benzerliklerine dayanarak, ilgili şapkalı mantar I. mytiliodora olarak kabul edilmiştir. Bu sonuç aynı zamanda "Ank Akata \& Altuntaş 167” ile yakın akraba mantarlar arasındaki morfolojik ve ekolojik benzerliklerin değerlendirilmesi ile de desteklenmiştir.

Araştırma vurguları: Sonuç olarak, Ankara Üniversitesi Tandoğan Kampüsü'nden toplanan bazidiyomalar "Inocybe mytiliodora" yı temsil eder ve Türkiye için ilk kayıttır.

Anahtar Kelimeler: Inocybe mytiliodora, nrLSU, Ankara, Molecular Filogeni, Yeni Kayit

\section{Introduction}

Inocybe is an ectomycorrhizal genus of the family Inocybaceae within the order Agaricales (Basidiomycota). This genus contains about 500 species, whose distribution range from the tropics to the arctic regions, particularly occurring in coniferous and deciduous woodlands (Akata, 2017; Kirk, Cannon, Minter \& Stalpers, 2008).

Inocybe members are characterized by small to medium-sized, collybioid, tricholomatoid or mycenoid fruiting bodies, smooth to fibrillose, squamulose or squarrose, whitish, grey, yellowish, pale brownish or red-brownish pileus, occasionally with red, greenish or purplish tinge, initially conical to campanulate, later convex, plano-convex to applanate, adnate, adnexed or free lamellae, mostly white, greyish, brownish with yellowish, greenish or olivaceous tinge, central and cylindrical stipe, usually spermatic, rarely aromatic or fishy odor, snuff 
brown spore print, smooth to tuberculate, angular, nodulose, amygdaloid, or phaseoliform, clavate basidia, mostly thickwalled and metuloid, more rarely thin-walled globose or pyriform cystidia (Knudsen \& Vesterholt, 2008; Kuyper, 1986).

According to the current literature on Turkish mycobiota (Akata, 2017; Akata \& Uzun, 2017; Akata, Kabaktepe, Sevindik, \& Akgül, 2018; Akata, Altuntaş \& Kabaktepe, 2019; Doğan \& Kurt, 2016; Sesli \& Denchev, 2008; Türkekul \& Işık, 2016; Uzun and Acar, 2018), more than 75 Inocybe species have so far been registered from Turkey but there was not any report of I. mytiliodora Stangl \& Vauras to date.

The current study aims to contribute to the Turkish Inocybe.

\section{Materials and Methods}

In this study, both conventional and molecular identifications including evaluation of macro and micromorphologies of the samples and nuclear ribosomal large subunit (nrLSU) sequencing were used to characterize the fungi sample (Ank Akata \& Altuntaş 167) collected from Ankara University Tandoğan Campus.

\section{Morphological Characterization}

Basidiomata were collected from Ankara University Tandoğan Campus (Ankara) on September 2, 2018. During the fieldwork, habitat and macroscopic properties of the Basidiomata were noted. Relevant macroscopic and microscopic data were obtained using standard techniques and identification was performed according to the studies by Hobart and Henrici (2011), Knudsen and Vesterholt (2008) and Stangl and Vauras (1987). The identified samples were kept at Ankara University Herbarium (ANK).

\section{Molecular Characterization \\ DNA Isolation}

The genomic DNAs of the specimens were extracted from the sporophores, according to the method using CTAB extraction buffer (Doyle \& Doyle 1987). NanoDrop Lite UVVis Spectrophotometer (Thermofisher) was utilized to determine the DNA purity and concentration.

\section{PCR Amplification and Sequencing}

The nuclear ribosomal large subunit (nrLSU) region of the rDNA was amplified by PCR using the universal LR5 and LR0R oligonucleotide primers (Stielow et al., 2015). PCR was set up in a reaction volume of $35 \mu 1$. The final concentrations of the PCR ingredients were designated as follows: $1 \times$ Taq DNA polymerase buffer, 2 units of Taq DNA polymerase (Fermentas), 0,4 $\mathrm{mM}$ dNTPs, $2 \mathrm{mM} \mathrm{MgCl} 2$, and $10 \mathrm{pmol}$ of both LR5 and LR0R primers. PCR was conducted in a Thermal Cycler (ABI MiniAmp Plus) with the below mentioned thermal cycling conditions: first denaturation step of $94^{\circ} \mathrm{C}$ for 5 minutes, pursued by 35 cycles of $94^{\circ} \mathrm{C}$ for 25 seconds, $55^{\circ} \mathrm{C}$ for 25 seconds, and $72^{\circ} \mathrm{C}$ for 90 seconds, and a last elongation step of 10 minutes at $72^{\circ} \mathrm{C}$. The PCR products were electrophoretically analyzed in $1.3 \%$ agarose gel including the sybr safe dye. DNA marker (GeneRuler 100 bp Plus DNA Ladder, Thermofisher) was utilized for the sizing of the amplicons. The PCR products were sequenced bidirectionally by using the LR5 and LROR primers and the standard Sanger dideoxy chain termination method at the laboratory of BM Labosis (Ankara, Turkey).

\section{Sequence Analysis}

The amplified fragments were sequenced and the 28S rDNA region sequences from several other fungal species were obtained from GenBank to compare with the 'Ank Akata \& Altuntaş 167' (Supplementary Table 1). The sequences were assembled using Geneious Prime 2019.1.3 software (Biomatters Ltd) and used for the sequence identity analysis with Basic Local Alignment Search Tool (BLAST). The DNA sequences were then aligned using the CLUSTALW. Molecular phylogenetic analyses were conducted by using the maximum likelihood method with the Kimura 2-parameter substitution model via MEGA7 software (Tamura et al., 2011). One thousand bootstrap replicates were applied (Felsenstein, 1985).

\section{Results}

Inocybe mytiliodora Stangl \& Vauras (Figure1, 2). 
Macroscopic and Microscopic Features

Pileus 10-15 $\mathrm{mm}$ across, hemispherical when young, later campanulate or convex to almost plane with a distinct umbo. Surface fibrillose to scaly, tawny, yellowish, red to buff. Margin strongly incurved. Cortina whitish. Lamellae greyish when young, then sand-colored to light brown. Stipe 25-35 $\times 5$ $\mathrm{mm}$, whitish at the apex, concolorous with pileus. Flesh whitish. Taste unpleasant. Odor distinctly mussel-like (Mytilus edulis). Basidia $25-30 \times 9-10 \mu \mathrm{m}$, clavate with 4 sterigmata. Spores 6-7 $\times$ 9-10 $\mu \mathrm{m}$, smooth, amygdaliform, thick-walled, yellowishbrown. Cheilocystidia 14-21 $\times$ 40-55 $\mu \mathrm{m}$, metuloid, clavate, pyriform or utriform. Pleurocystidia were similar to cheilocystidia. Caulocystidia not observed. Pileipellis 8-12 $\mu \mathrm{m}$ thick, composed of periclinal hyphae.

Ecology: Summer to autumn, under deciduous trees (Knudsen and Vesterholt, 2008).

Specimen examined: TURKEY, Ankara: Ankara University Tandoğan Campus, under pedunculate oak (Quercus robur L.), $867 \mathrm{~m}$, $39^{\circ} 56^{\prime} \mathrm{N}, 32^{\circ} 50^{\prime} \mathrm{E}, 02.09 .2018$, ANK Akata \& Altuntaş 167. In the current study, the evolutionary history was revealed by using the Maximum Likelihood algorithm with the K2substitution model for the phylogenetic relationship. The tree with the highest $\log$ likelihood (-2171.46) was shown in Figure 3.

Through phylogenetic analysis, we revealed two distinct clades of fungal species as well as an outgroup. The major clade (Clade 1) included all Inocybe species together with 'Ank Akata \& Altuntaş 167' which was collected from Ankara University Tandoğan Campus (Ankara), while the other clade only included I. tenebrosa. On the other hand, Simocybe sp. was branched far from other fungi species and generated an outgroup as expected with a bootstrap value of $100 \%$ (Figure 3). Just as a side note, more firm conclusions will be possible in future studies when more Inocybe species may be included in phylogenetic analyses.

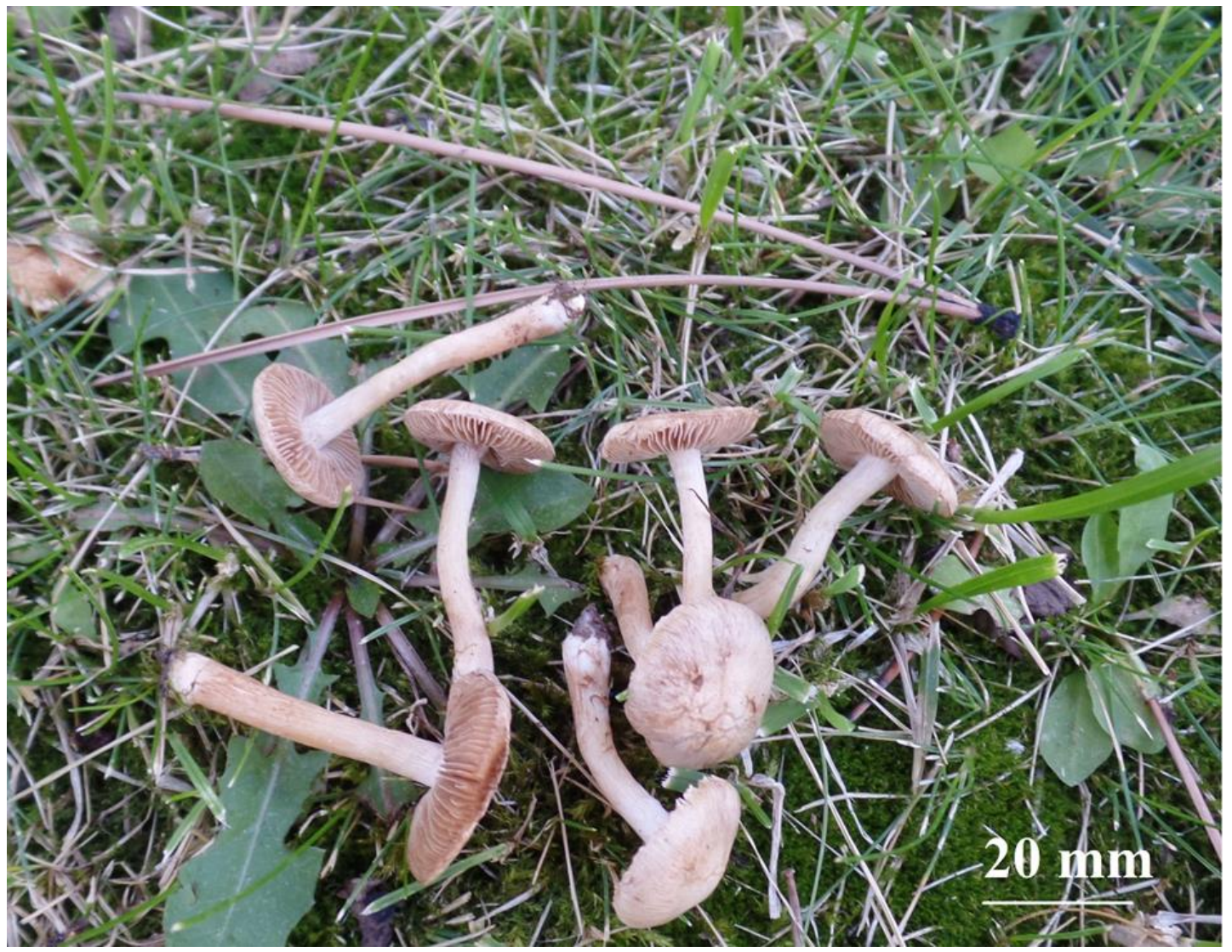

Figure 1. Basidiomata of Inocybe mytiliodora 


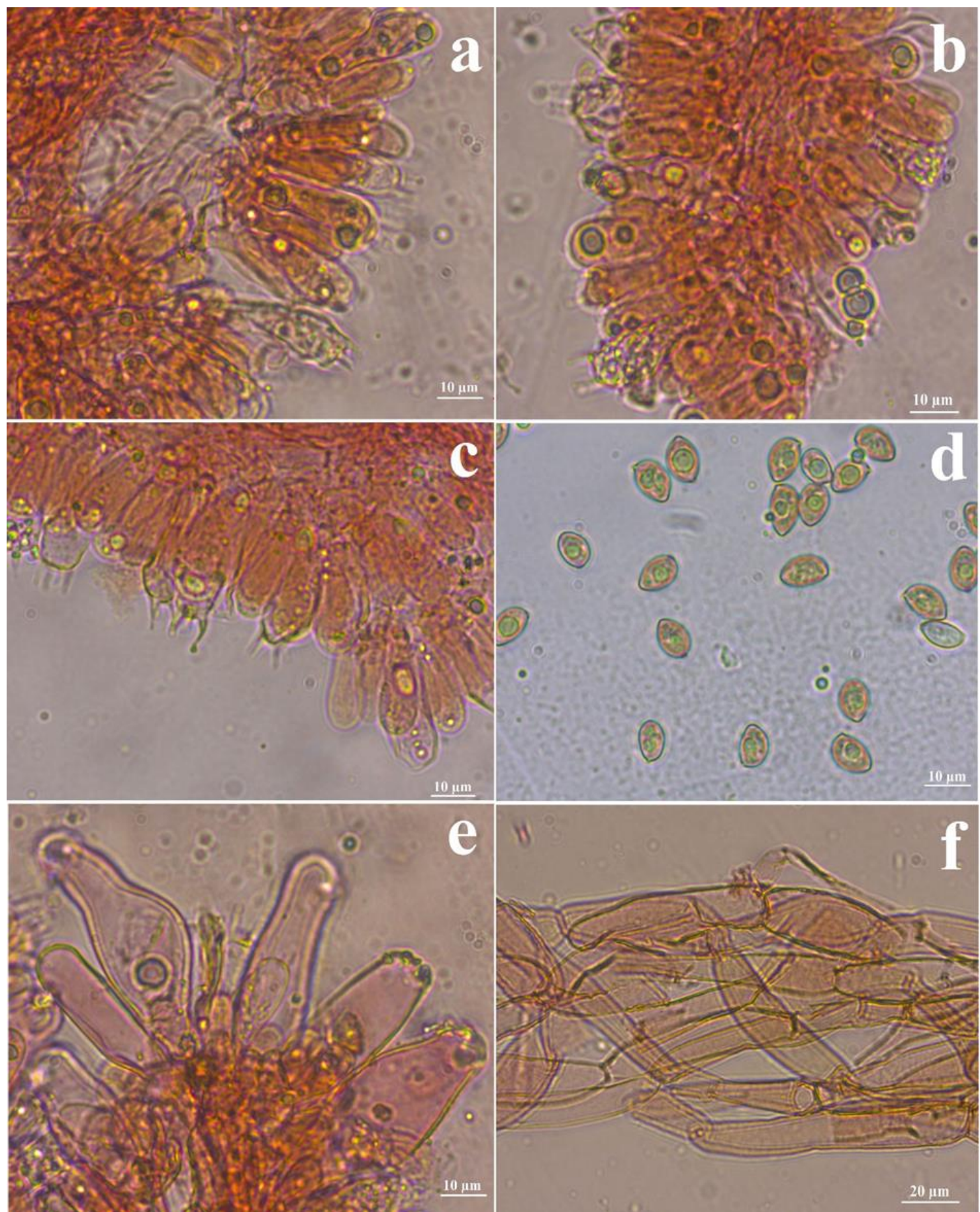

Figure 2. Inocybe mytiliodora: a-c. basidia. d. spores. e. cheilocystidia. f. pileipellis. 


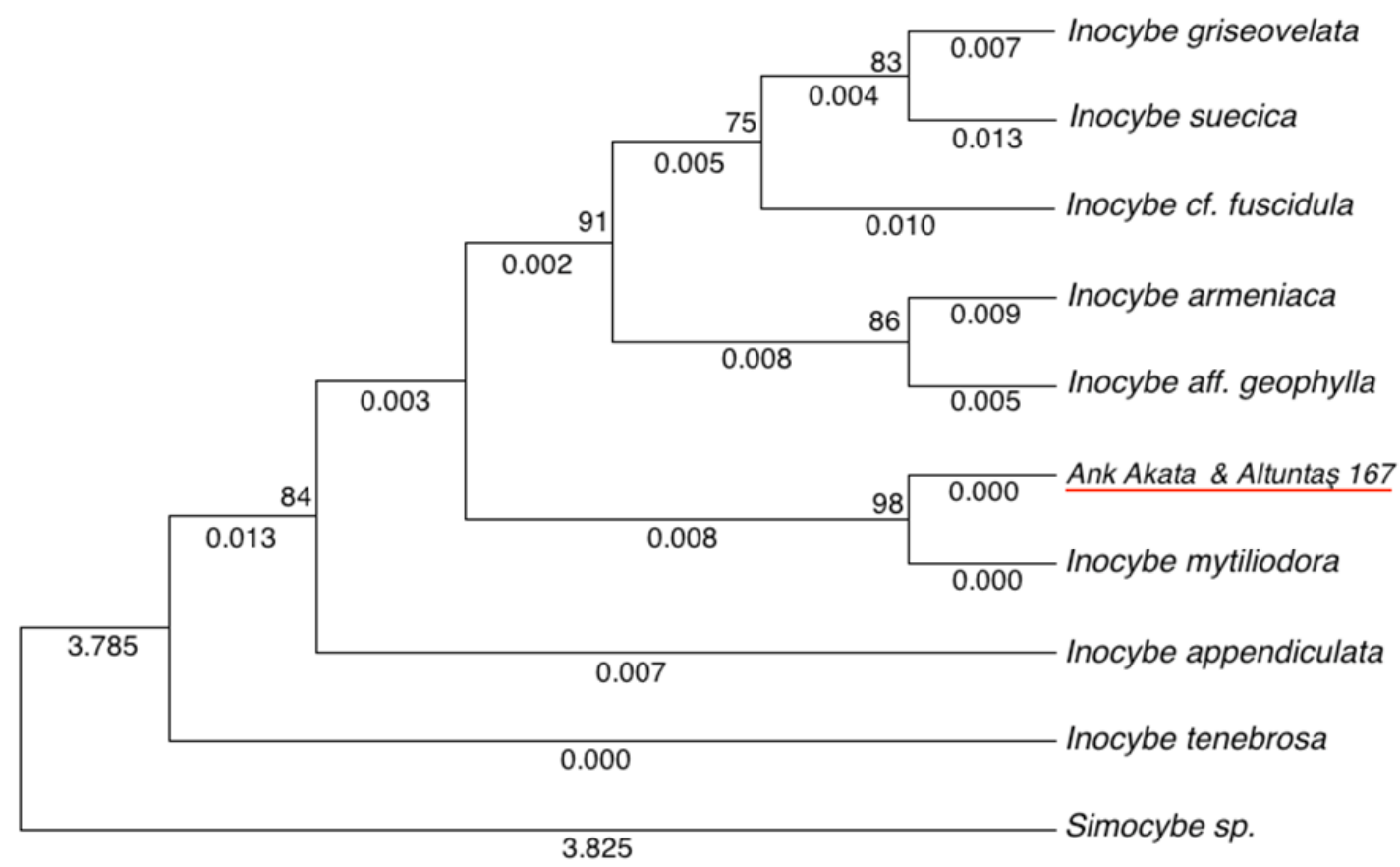

Figure 3. The maximum likelihood topology tree showing the genetic relationships of 10 fungi species with each other based on nrLSU region. Bootstrap values from 1000 bootstrap replicates were shown above the branches. Branch lengths were indicated below the branches.

Moreover, the phylogenetic tree based on nrLSU sequences provided evidence for $100 \%$ similarity of newly identified 'Ank Akata \& Altuntaş 167' to Inocybe mytiliodora with a bootstrap value of $98 \%$ (Figure 3 ).

Taking both the molecular and morphological data into account, we can conclude that 'Ank Akata \& Altuntaş 167' is a specimen of I. mytiliodora and this study can be considered to be the first study that reveals the presence of I. mytiliodora in Turkey.

\section{Discussion}

The most important characteristics of $I$. mytiliodora are clavate basidia, smooth and thick-walled spores; metuloid, broad and thick-walled hymenial cystidia, and mussellike odor. I. bongardii (Weinm.) Quél., I. fulviceps Murrill, I. mucidiolens (Grund \& D.E.Stuntz) Matheny, I. pallidicremea Grund \& D.E.Stuntz, I. personata Kühner, I. geraniodora J.Favre, and I. pelargonium Kühner possess fishy or pelargonium-like odor but they can easily be separated from I. mytiliodora by their distinct morphology. $I$. pedemontana may also be confused with $I$. mytiliodora because of their similar morphology, ecology, and odor but the former species is easily distinguished from the latter by the metuloid caulocystidia at the upper part of the stipe (Knudsen and Vesterholt, 2008; Stangl and Vauras, 1988).

nrLSU (nuclear ribosomal large subunit) is a widely used DNA barcoding marker, which is useful for the identification of fungal samples at the species level (Xiao et al., 2018). As the data of morphological traits is not sufficient alone for precise identification of fungi species, the use of sequence data from conserved DNA regions such as nrITS and nrLSU is considered to be an important tool for researchers with expertise in taxonomy and systematics of fungi since the last three decades (Vellinga, 2004; Chakraborty, Vizzini \& Das, 2018; Xiao et al., 2018).

Moreover, the ribosomal RNA region is the most common and abundant DNA barcoding marker, which provides an important source for the researchers to make comparisons of data obtained from their studies with the one found in the GenBank database. For this reason, we used nrLSU region for the molecular identification of this agaric. The new record found $100 \%$ 
genetically similar to Inocybe mytiliodora (GenBank ID: JN974947) and this result is also supported by morphological findings (Figures 1, 2 and 3).

As a result, I. mytiliodora is the first record for Turkey and supports the richness of fungal diversity in Ankara University Tandoğan Campus.

\section{Acknowledgments}

We are thankful to Ankara University's Central Research Funding Unit (Project no: 18B0430001) for its financial support. Also, we appreciate Dr. Ergin Sahin for his constructive feedback.

\section{References}

Akata, I. (2017). Macrofungal Diversity of Belgrad Forest (İstanbul). Kastamonu Üniversitesi Orman Fakültesi Dergisi, 17(1), 150-164.

Akata, I. \& Uzun, Y. (2017). Macrofungi Determined in Uzungöl Nature Park (Trabzon). Trakya University Journal of Natural Sciences, 18(1), 15-24.

Akata, I., Kabaktepe, Ş., Sevindik, M. \& Akgül, H. (2018). Macrofungi determined in Yuvacık Basin (Kocaeli) and its close environs. Kastamonu University Journal of Forestry Faculty, 18(2), 152-163.

Akata, I., Altuntaş, D. \& Kabaktepe Ş. (2019). Fungi Determined in Ankara University Tandoğan Campus Area (Ankara-Turkey). Trakya University Journal of Natural Sciences, 20(1), 47-55.

Chakraborty, D., Vizzini, A. \& Das, K. (2018). Two new species and one new record of the genus Tylopilus (Boletaceae) from Indian Himalaya with morphological details and phylogenetic estimations. MycoKeys, (33), 103.

Doğan, H. H. \& Kurt, F. (2016). New macrofungi records from Turkey and macrofungal diversity of Pozant1-Adana. Turkish Journal of Botany, 40(2), 209-217.

Doyle, J.J. \& Doyle, J.L. (1987). A rapid DNA isolation procedure for small quantities of fresh leaf tissue. Phytochemical Bulletin, 19, 11-15.
Felsenstein, J. (1985). Confidence limits on phylogenies: an approach using the bootstrap. Evolution, 39(4), 783-791.

Hobart, C. \& Henrici, A. (2011). Inocybe Mytiliodora New to Britain. Field Mycology, 12(3), 77-80.

Kirk, P. M., Cannon, P. F., Minter, D. W. \& Stalpers, J. A. (2008). Dictionary of the fungi 10th edition. CAB International, Wallingford, $U K$.

Knudsen, H. \& Versterholt, J. (2008). Funga Nordica. Nordsvamp. Copenhagen, Denmark.

Kuyper, T. W. (1986). A revision of the genus Inocybe in Europe. I. Subgenus Inosperma and the smooth-spored species of subgenus Inocybe. Persoonia-Supplement, 3(1), 1-247.

Sesli, E., \& Denchev, C. M. (2008). Checklists of the myxomycetes, larger ascomycetes, and larger basidiomycetes in Turkey. Mycotaxon.

Stangl, J. \& Vauras, J. (1987). Über das Genus Inocybe in Finnland. Die neuen Arten I. mytiliodora und I. urceolicystis. Karstenia, 27(1), 15-21.

Stielow, J.B., Lévesque, C.A., Seifert, K.A., Meyer, W., Iriny, L., Smits, D., ... Robert, V. (2015). One fungus, which genes? Development and assessment of universal primers for potential secondary fungal DNA barcodes. Persoonia, 35: 242-263.

Tamura, K., Peterson, D., Peterson, N., Stecher, G., Nei, M. \& Kumar, S. (2011). MEGA5: molecular evolutionary genetics analysis using maximum likelihood, evolutionary distance, and maximum parsimony methods. Molecular biology and evolution, 28(10), 2731-2739.

Türkekul, İ. \& Işık, H. (2016). Bozatalan (Tokat) Yöresi Makrofunguslar1. Kafkas Üniversitesi Fen Bilimleri Enstitüsü Dergisi, 9(1), 5-11.

Uzun, Y. \& Acar, İ. (2018). A new Inocybe (Fr.) Fr. record for Turkish macrofungi. Anatolian Journal of Botany, 2(1), 10-12.

Vellinga, E. C. (2004). Genera in the family Agaricaceae: evidence from nrITS and nrLSU sequences. Mycological Research, 108(4), 354-377.

Xiao, Y. P., Wen, T. C., Hongsanan, S., Jeewon, R., Luangsa-ard, J. J., Brooks, S., ... \& Hyde, K. D. (2018). Multigene phylogenetics of Polycephalomyces (Ophiocordycipitaceae, Hypocreales), with two new species from Thailand. Scientific Reports, 8(1), 18087. 